\title{
Postharvest Rot Diseases of Some Stone Fruits Collected From Jeddah City, Saudi Arabia
}

\author{
Hawazen Hamid Khallaf, Lubna S. Nawar and Fatma H. Tawfiq \\ Biology Department, Faculty of Science, King Abdulaziz University, Jeddah, Saudi Arabia.
}

\begin{abstract}
The present investigation was designed to study intensively, the fungi associated with stone-fruits (apricots, cherries, peaches and plums) that causing rots for these kinds of fruits. Survey for the mycoflora of those fruits post-harvesting and during storage periods were carried out. The highest percentage of infection was recorded in fruits with street sellers and the smallest one was recorded in cold storage cars. Mycoflora of the apparently healthy fruits included Alternaria, Aspergillus, Diplodia, Fusarium, Monilinia, Penicillium, Rhizopus, Stemphylium and Thamnidium. The mycoflora of rotted fruits did not differ from healthy fruits, but the total counts of dominant species were different. Rhizopus stolonifer, Penicillium expansum, Aspergillus niger and Monilinia fruticola were the most dominant species. Those four species has been chosen for further physiological and pathogenicity studies. The tested fungi showed an extensive growth on peptone glucose agar; potato dextrose agar (PDA) and molt extract agar media. The optimum temperature for Aspergillus niger growth was $25-30^{\circ} \mathrm{C}$ and it was $30^{\circ} \mathrm{C}$ for the other tested fungi. The neutral $\mathrm{pH}$ values ( $\mathrm{pH}$ 7) encouraged the growth of the tested fungi. Acetic acid and 6\% chitosan showed a high inhibitory effect against the tested fungi. The best inhibitory effect was recorded with 6\% chitosan, followed with acetic acid and then $3 \%$ chitosan. Ozone water showed lesser inhibition effect. In conclusion, fruit are generally infected by fungi and lower temperature and $\mathrm{pH}$ decreased fungal infection which increased in case injured fruits. Thus, fruits preservation and sales must be carried out under clean and cold conditions.
\end{abstract}

Keywords: Aspergillus, Rot fungi, peach, chitosan, infection, Apricot Peach, Plum, Cherry

\section{Introduction}

Fruits are affected by several fungal diseases that cause a heavy losse in their production and one of these fungi is the genus Aspergillus. Aspergillus flavus was isolated by Jamaludin (1980) from infected peach fruits while Maiti et al., (1981) studied the emergence of the new fungus Glomerella cingulata on plum fruits. Saikia and Puzari (1982) isolated Geotricum candidum that cause rot plum fruits while Gintig et al., (1996) isolated Rhizopus sp. from peaches, grown in North Carolina, which was widespread in the soil and the remnants of plant waste. Zhull et al., (1996) isolated Alternaria tenius from the fruits of infected apricot and they added that this fungus caused the display of dark spots (black spot) on each of the leaves and fruits. Wells and Gerdts (1971) found that the rot of stone fruit was caused by Rhizopus stolonifer and sometimes by Aspergillus niger and Penicillium expansum. In Pakistan, Bhragava et al., (1978) isolated the genera Trichothecium, Rhizopus, Fusarium and Alternaria from plum infected fruits, which was commercially marketed. Rittenburg and Hendrix (1983) isolated Botrysphira. sp and Glumerella cingulata from the infected fruits in the USA and two fungi cause quite rotten to immature and mature peachs. Latter, El-Tobshy et al., (1986) said that Penicillium sp., $R$. stolonifer, A. niger, Getricum candidum and Alternaria sp. were more prevalent on plum, peach, apricot and added that the main post-harvest fungi were $R$. stolonifer (causes soft rot) and B. cineria (causes mold soft gray) to fruit. Spada (1995) found that $M$. laxa is the most common fungus, causing peach mold while the fungus $R$. nigricans, $M$. fructicola, $B$. cinerea and $P$. expansum were less common. In Italy, Fanti et al., (1996) estimated some fungi on stone fruits like M. laxa, Taphriana defarmans M. fractigena, Cladosporium carpophilum, Rhizopus sp. and Penicillium expansum. In Italy, the fungus Monilinia sp. caused a great loss in peaches, apricots and nectarines during the marketing and distribution of the fruits and this caused many damage and loss (Tosi et al., 1996). Catarner (1997) reported that M. laxa, and M. fructogena caused the main injury in the trees and the fruits of cherry in Poland. In the study of Ritchie (2000), the most important diseases affecting fruits of cherry was caused by M. fructicola which was one of the most important fungi that infect apricot fruits. Further, Gualandizzi et al., (2001) indicated that M. laxa, R. stolonifer and $B$. cineria were more common on the fruits of plum, peach, apricot before and after harvest while M. laxa and M. fructgena were mainly infected stone fruits (Kovacs, 2001). Dzhafarov (2002) reported that A. niger, B. cineria, Phoma armenicea, M. laxa can infected the fruits of apricots while about 39 fungal isolate belonging to 16 genera of fungi were recorded on post-harvest decay apple, orange, banana, mango and grape fruits in Sana'a market, Yemen (Abdullah et al., 2016).

It is well known that, strains of A. niger have the ability to secrete pectin methyl esterase and cellulase which decompose pectin and cellulose (Chopra et al., 1989, Prasad et al., 1989). Kuzmanova et al., (1991) 
isolated the rot fungi, A. niger and P. funiculosum which had the ability to secrete cellulase enzymes. The isolates of Aspergillus, Penicilium and Rhizopus caused rot of many fruits due to secretion of cellulase and pectinase (El-Shaieb and Malibari, 1995). Dahm et al., (1997) studied cellulase and pectinase activities in $R$. solani, F. oxysporum and T. virido. Ugwanyiana and Obeta (1997) isolated A. niger, Botryodiplodia, Corticium rolfsi, Getricum candidum and $F$. oxysporum with cellulose activity from infected fruit tissue. In studies carried out by El-Shaieb and Malibari (1998) on the enzymatic activity of the fungi that cause soft rot of vegetables and fruit, the greatest enzymatic activities was for $A$. niger and $R$. stolonifer. In Yemen and from rotted fruits samples, several fungal isolates were obtained on Potato dextrose agar after 7 days of incubation. The isolated fungi were identified as Penicillium expansum from apple, $P$. glabrum from grape, Colletotrichum musae from banana, Aspergillus terreus from orange, A. niger from mango (Abdullah et al., 2016).

The inhibitory effect of some compounds on rotted fruit was studied, El-Ghaouth et al., (1991, 1992) reported that the chitosan was very effective in preventing microbial spores and growth of $B$. cineria and $R$. stolonifer. Moreover, they find that at $1.5 \mathrm{mg} / \mathrm{ml}$ chitosan, there are changes in the morphology of $R$. stonolifer. Benhamou (1992) detected that chitosan at $3-5 \mathrm{mg} / \mathrm{ml}$ prevent the growth $F$. oxysporum and microscopic observations indicated that chitosan caused morphological and anatomical changes which led to a change in the shape and the occurrence of malformations. Fang et al., (1994) told that the chilling effect of chitosan against $A$. niger was increased at $\mathrm{pH} 5.4$ while Li et al. (1997) demonstrated that chitosan has a dampening effect on preventing $R$. stolonifer growth and M. fructicola. Chitosan reduce the growth of Mucor ramosus at $1 \mathrm{~g} / \mathrm{l}$ (Roller and Covill, 1999). The effect of acetic acid on fungi was studied by Sholberg and Gance (1996). Yarahmadi et al. (2014) found that vanillin greater than $1 \mathrm{~g} / \mathrm{l}$ and $3 \mathrm{~g} / 1$ chitosan had a significant effect on fungal growth (100\% inhibition) and they added that $1 \%$ of chemical acetic acid reveal the highest inhibitory effects on growth of Rhizopus but verjuice (natural acetic acid), 60 and $80 \mathrm{ml} / 1$ control Rhizopus grown. Studies on fruits rotting fungi in Jeddah are rare and this study was carried out to determine the biodiversity of post-harvest decay fungi of apricots, cherries, peaches and plums fruits sold in local markets in Jeddah city, Saudi Arabia.

\section{Samples collection}

\section{Material and Methods}

Samples of the fruits of Plum (Plum domestical L), Peach (Prunus persica Batsch L.), Cherry (Prunus avium L.) and Apricot (Prunus armeniaca L.) were obtained (100 unit of each) from commercial super markets, grocery stores, cold storage cars and street vendors in Jeddah. The fruits were collected randomly and preserved in clean plastic cans at $-4 \mathrm{C}$ and transferred directly to the lab. The mean value of temperature was recorded.

\section{Fungal isolation and identification}

Fungi accompanying mature or over mature fruits were isolated and identified. Healthy fruits without any symptoms (appeared normal), 100 fruit from each of the plum, peaches, cherries and apricots samples that have been taken, washed with sterile water, and the associated fungi were isolated on potato dextrose agar (PDA). Similarly, fungi associated with diseased fruits were also determined. For isolation of fungi associated with the infected fruits, different parts of the affected areas were taken by scalpel or sterile forceps (depending on the nature of the injury) and placed in Petri dishes containing $20 \mathrm{ml}$ of PDA where it was put in each dish 4 parts. All dishes were incubated at $25^{\circ} \mathrm{C}$ for 3-5 days. The appeared fungi were counted and the percentage for the fungi was calculated. Various molds were purified and identified according to Thom and Raper (1945); Raper and Thom (1949); Gilman (1957); Subramanian (1971); Barnett and Hunter (1972) and Nelson et al., (1983).

\section{Chemical analysis of the examined fruits:}

The $\mathrm{pH}$ of the fruits was estimated by the use of measuring $\mathrm{pH}$ device (Digital $\mathrm{pH}$ Meter 525). Total soluble sugars, phenols, total solids and total soluble matters were also estimated according to Allen et al. (1974).

\section{Pathogenicity of fungi associated with stone fruits}

Four types of fungi, Aspergillus niger, Monilinia fructicola, Penecillium expansum and Rhizopus stolonifer, are the most commonly associated with the varieties of the tested fruits (plum peach cherry apricot) and these fungi represented the highest percentage of incidence on the tested fruits. These fungi were subjected to some pathological and physiological and tests. About 100 fruits of each tested types were washed, surface sterilized using $0.05 \% \mathrm{Na}$ hypochlorite, washed again two times with sterile water, dried and divided into two groups. Healthy and injured fruits $(n=100)$. The two groups were sprayed with one of tested fungal suspension $\left(5 \times 10^{5}\right.$ spore $\left./ \mathrm{ml}\right)$. The fruits were left at room temperature $22-25^{\circ} \mathrm{C}$ for a week and Disease incidence was determined for healthy and injured fruits based on Wokocha (1990)

$$
\text { Disease incidence }(\mathrm{I})=\frac{\text { Number of fruits affected }}{\text { Total number of fruits }} \times 100
$$




\section{Effect of some factors on rot fungal growth}

Effect of some factors on the four fungi, A. niger, R. Stolonifer, M. fructicola and P. expansum had been studied on agar medium at different temperature and $\mathrm{pH}$. Fungal growth was measured using liner growth $(\mathrm{mm})$. A disc of fungal growth (diameter $5 \mathrm{~mm}$ ) was put in the middle of the dish and all plates were incubated for 7 days. Four replicates were determined for each experiment.

\section{Effect of different media on fungal growth}

The fungal growth of the four fungal isolates, A. niger, R. Stolonifer, M. fructicola and P. expansum on the five different agar medium was compared. The six different nutritional media were agar Potato dextrose agar, Malt extract agar, Glucose peptone agar), Capek's agar, Yeast extract sucrose and Richard's agar. All media were sterilized at $1.5 \mathrm{~atm}$. and $120^{\circ} \mathrm{C}$ for $15 \mathrm{~min}$. All inoculated plates were incubated at $25^{\circ} \mathrm{C}$ for 7 days and growth (liner growth $\mathrm{mm}$ ) was determined for each fungus.

\section{Effect of different temperature on fungal growth}

Effect of different temperatures $\left(5-40^{\circ} \mathrm{C}\right)$ on fungal growth was determined using liner growth method. On PDA medium, growth of A. niger, R. Stolonifer, M. fructicola and P. expansum was determined after 7 days.

\section{Effect of hydrogen-ion concentration $(\mathrm{pH})$ on fungal growth}

In this study, the effect of different hydrogen ion concentrations ( $\mathrm{pH} 3.0,4.0,5.0,6.0,6.6,7.0,7.5,8.0$ and 9.0) using PDA on growth of the four tested fungi, A. niger, $R$. Stolonifer, M. fructicola and P. expansum was determined. All Petri dishes were incubated at the optimum temperatures for each fungus and linear growth (average diameters of the fungal colony) was determined for each $\mathrm{pH}$ value.

\section{Effect of some chemical on fungal growth}

Effect of Acetic acid (2\% v/v), Chitosan (3 and 6\% w/v) and Ozone (1\% v/v) on fungal growth were determined on PDA medium using agar well diffusion method described by Bauer et al., (1966).

\section{Estimation of enzymatic activity}

We've been the study of enzymatic activity of the fungi by measuring their ability to secrete hydrolysis enzymes for pectin and cellulose.

\section{Detection of the pectin enzyme activity}

This experiment was conducted to study the ability of fungi to secrete Pectin methyl estrase (PME) and Poly galacturonase (PG) and which hydrolize pectin. Enzyme production was tested on liquid medium containing pectin (Dhingra and Sinclair, 1985) and was composed of Ammonium nitrate $\left(\mathrm{NH}_{4} \mathrm{NO}_{3}\right) 0.1 \%$, $\mathrm{KH}_{2} \mathrm{PO}_{4} 0.1 \%, \mathrm{Mg}_{2} \mathrm{SO}_{4} 0.05 \%$ and Apple pectin $1.5 \%$. The four selected fungi were incubated at $25^{\circ} \mathrm{C}$ for two weeks without shaking, and then the filtrate was collected, centrifuged at $1000 \mathrm{rpm}$ for $5 \mathrm{~min}$. under conditions of cooling (Denly BR 401). The supernatant contained the crude enzyme and then the following tests were conducted to assess the activity of the pectin enzyme. Pectin methyl estrase (PME) activity was calibrated by Titration Method (Smith, 1958). About $5 \mathrm{ml}$ of crude enzyme was added to $20 \mathrm{ml}$ of pectin solution $(1.5 \% \mathrm{w} / \mathrm{v})$ at $\mathrm{pH} 7$, the mixture was incubated at $30^{\circ} \mathrm{C}$ for 24 hours, and then 3-4 drops of chloroform was added. The enzyme activity was calculates by the amount consumed of sodium hydroxide $(\mathrm{ml})$ needed to neutralize the carboxyl groups in the mixture and resulting from the decomposition of pectin enzyme.

Estimation Poly galacturonase activity was carried out by calculation of the percentage of the decrease in the viscosity of $1 \%$ solution of Poly galacturonic acid using a crude enzyme. About $5 \mathrm{ml}$ of the crude enzyme solution was added to $5 \mathrm{ml}$ of $1 \%$ Poly galacturonic acid at $\mathrm{pH} 5$ and the viscosity was estimated (Nasuno and Starr, 1966).

\section{Measurement of the cellulase enzyme activity}

Fungi were grown in medium containing $\mathrm{MgSO}_{4} .7 \mathrm{H}_{2} \mathrm{O} 0.05 \%, \mathrm{KCl} 0.05 \%, \mathrm{FeSO}_{4} .7 \mathrm{H}_{2} \mathrm{O} 0.001 \%, \mathrm{~L}$ Argenin $0.3 \%, \mathrm{KH}_{2} \mathrm{PO}_{4} 1.8 \%, \mathrm{~K}_{2} \mathrm{HPO}_{4} 1.2 \%$, carboxy methyl cellulose $2 \%$ at $25^{\circ} \mathrm{C}$ for two weeks and cellulase activity was determined (Talboy and Busch, 1970) by the decrease in viscosity using $1.2 \%$ of the carboxy methyl cellulose solution in a buffer solution. Moreover, quantification of glucose resulting from the analysis of cellulose (units/ $\mu \mathrm{mol}$ glucose $/ \mathrm{h} / \mathrm{ml}$ of the crude enzyme) was determined.

\section{Inhibitory effect of acetic acid and chitosan and water ozone on the growth of fungi that cause rot}

In this experiment, Potato dextrose agar plates, inoculated with fungal suspension $\left(4 \times 10^{5} \mathrm{spore} / \mathrm{ml}\right)$ has been used and a hole of $5 \mathrm{~mm}$ diameter were made in each plate using sterile Cork porer and $100 \mu \mathrm{l}$ of each of tested solution, $1 \%$ acetic acid, 3 and $6 \%$ chitosan solution and ozone water were added to each well. The 
dishes were left in the incubator for 7 days, then inhibition zone diameter was measured and the percentage of inhibition in each of the four fungi was calculating.

\section{Results}

The present investigation has been conducted to study the rot fungi of stone-fruits (plums, peaches, cherries, and apricots) that widespread used in Saudi Arabia (Fig. 1). The rot fungi were studied at post- harvest, during storage and marketing. Those fungi have an economic importance due to their capabilities to cause rots and deteriorations to stone-fruits, losing in the crop productivity and hence great effect in the crops as whole.

This study dealt with, isolation and identification of fungi causing rots to marketable stone- fruits at Jeddah city. The physiological and pathogenicity studies for the most important fungi isolated from stone fruits were determined. The percentage of infected fruits with different rots at different sales markets (cooling cars, supermarkets, small groceries and street sellers) was estimated. The highest percentage for fungal infection (55\%) was recorded in fruits with street sellers. The small groceries ranked second, and recorded $40.1 \%$, followed by supermarkets $24 \%$ and finally cooling cars with $13.2 \%$ (Table 1 ). The $\mathrm{pH}$ values for the studied fruits were measured. The apricot fruits showed the lowest $\mathrm{pH}$ value ( $\mathrm{pH} 3.8)$, followed by plums ( $\mathrm{pH} 4.1)$, then peaches ( $\mathrm{pH} 4.9)$ and finally cherry fruits $(\mathrm{pH} 7.1)$. The total acidity, total soluble sugars, total phenols and total solid materials for the tested fruits were studied (Table 2). The results showed a degree of variations, whereas the percentages of acidity were $0.53,0.45,0.11$ and $0.067 \%$ for cherries, plums, apricots and peaches, respectively. The values of total soluble sugars were $12.53,11.94,9.65$ and $8.1 \mathrm{mg} / \mathrm{g}$ for cherries, plums, apricots and peaches, respectively. The measurements of total solid materials were $16.17 \%$ in cherries, $15.17 \%$ in plums, $11.7 \%$ in apricots, and $9.33 \%$ in peaches. The total phenols values were $0.673,0.394,0.229$ and 0.187 $\mathrm{mg} / \mathrm{g}$ for plums, cherries, peaches and apricots, respectively.
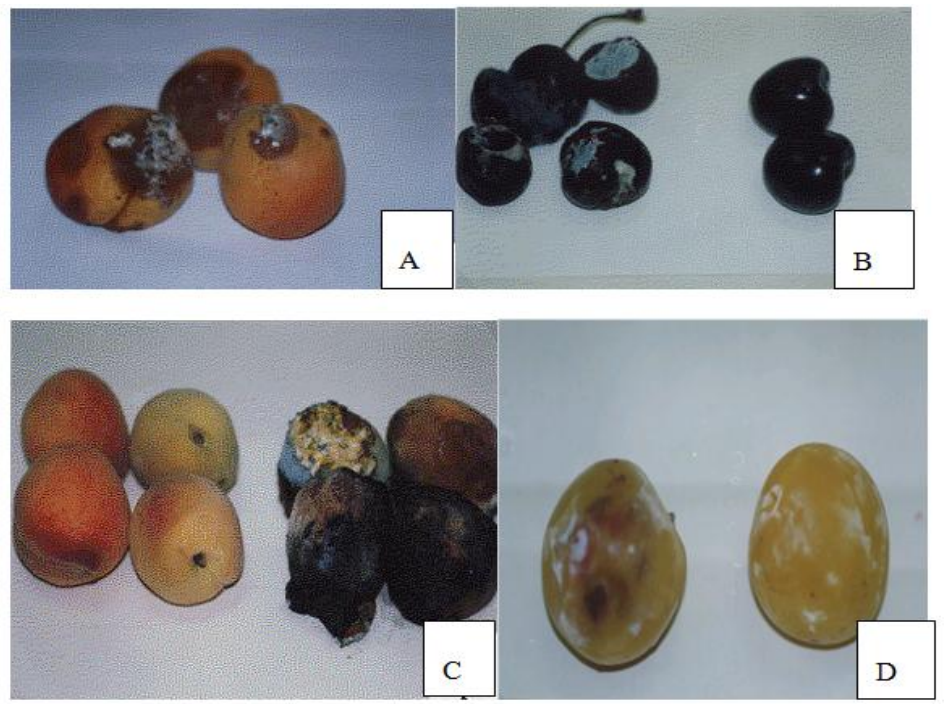

Fig 1. Healthy and fungal infected fruits collected from Jeddah, A: Apricot, B: Cherry, C: Peach and D: Plum

Studying mycoflora that associated with the apparently healthy fruits on potato dextrose agar (PDA) was determined (Table 3). Seventeen fungal species belonged to 10 genera (Alternaria, Aspergillus, Diplodia, Fusarium, Monilinia, Penicillium, Rhizopus, Stemphylium and, Thamnidium) were identified. Moreover, eighteen species belonged to 11 genera were collected from rotted fruits on PDA medium. Rhizopus stolonifer, Penicillium expansum, Aspergillus niger and Monilinia fruticola were the most dominant species. They constituted 99.07, 94.97, 91.05 and 78.19\% of total fungi isolated from rotted fruits, respectively. Those four species has been chosen for further experimental work due to their pathogenic importance (Table 4).

The pathogenicity of the four tested species on plum, peach and apricot fruits was studied (Table 5). The wounded fruits that sprayed with spore suspension of the tested species and incubated at room temperature $\left(22-25^{\circ} \mathrm{C}\right)$ for one week showed the highest percentage $(72.6 \%)$ for infection in comparison with the percentage of infection $(27.8 \%)$ of unwounded fruits that sprayed with the same way. The results indicated that the highest percentages for infection were recorded for Rhizopus stolonifer on apricots (90\%), peaches (85\%) and plums (75\%). The lowest percentages were recorded by Monilinia fruticola on apricots (72\%), peaches $(67 \%)$ and plumes $(53 \%)$.

Some physiological studies were carried out to visualize the effect of some of environmental factors on the growth of the tested fungi. Six different agar media were used to study the effect of cultural medium on the growth of the tested fungi. Peptone glucose agar, potato dextrose agar (PDA), molt extract agar and yeast extract 
Table 1. Percentages of fungal infection of four types of fruits collected from different places at different temperatures $(\mathrm{N}=100)$.

\begin{tabular}{|l|l|l|l|l|}
\hline & $\begin{array}{l}\text { Street vendors } \\
\left(37-40^{\circ} \mathrm{C}\right)\end{array}$ & $\begin{array}{l}\text { Small grocery } \\
\text { stores }\left(20-23^{\circ} \mathrm{C}\right)\end{array}$ & $\begin{array}{l}\text { Super market } \\
\left(15-18^{\circ} \mathrm{C}\right)\end{array}$ & $\begin{array}{l}\text { Cold storage } \\
\text { cars }\left(10^{\circ} \mathrm{C}\right)\end{array}$ \\
\hline Apricots & 25 & 15 & 7.5 & 4.7 \\
\hline Cherry & 35 & 22 & 3.5 & 2 \\
\hline Peaches & 71 & 50.5 & 32 & 18.5 \\
\hline Plum & 60.5 & 49.5 & 31 & 19.5 \\
\hline Mean & 55 & 40.1 & 24 & 13.2 \\
\hline
\end{tabular}

Table 2. Acidity, soluble phenol, soluble sugars and total soluble solid of the four tested fruits

\begin{tabular}{|l|l|l|l|l|}
\hline Tested fruits & $\begin{array}{l}\text { Acidity } \\
\%\end{array}$ & Soluble phenols (mg/g) & Soluble sugars (mg/g) & Total soluble solid (\%) \\
\hline Apricots & 0.455 & 0.187 & 9.65 & 11.7 \\
\hline Cherry & 0.067 & 0.394 & 12.53 & 16.17 \\
\hline Peaches & 0.111 & 0.229 & 8.1 & 9.33 \\
\hline Plum & 0.533 & 0.673 & 11.94 & 15.17 \\
\hline
\end{tabular}

sucrose agar were the best media for the growth of the tested fungi. The radial growth of the colonies of the tested fungi was measured. Rhizopus stolonifer showed the faster rate in the radial growth for its colonies, and it followed with Monilinia fructicola and Aspergillus niger, while Penicillium expansum showed relatively slower rate (Table. The effect of different temperatures on the radial growth $(\mathrm{mm})$ for the tested fungi was studied. Rhizopus stolonifer showed fast growth whereas the mycelium growth completed on Petri dish (90 mm) after 4 days at optimum temperatures $\left(25-30^{\circ} \mathrm{C}\right)$. Aspergillus niger ranked second at the same optimum temperatures, then Monilinia fructicola at $30^{\circ} \mathrm{C}$ as optimum temperature. The results of dry weight were similar whereas Rhizopus stolonifer showed the best growth at $25-30^{\circ} \mathrm{C}$. Using PDA medium and the optimum temperatures (25$30^{\circ} \mathrm{C}$ ) the effect of $\mathrm{pH}$ on the growth of the tested fungi were studied. The optimum $\mathrm{pH}$ for growth of the tested fungi was $\mathrm{pH} 7$, whereas the growth of colonies completed after 4 days.

Table 3. The isolated fungi from four types of healthy appearance fruits, Apricot, Cherry, Plum and Peach.

\begin{tabular}{|l|l|l|l|l|l|l|}
\hline Fungal isolates & No. of isolates & Apricot & Cherry & Peach & Plum & $\%$ of fungi \\
\hline Alternaria tenius & 4 & 2 & 1 & - & 1 & 2.79 \\
\hline Aspergillus flavus & 10 & 2 & 3 & 2 & 3 & 6.99 \\
\hline Aspergillus humicola & 2 & 1 & 1 & - & - & 1.39 \\
\hline Aspergillus niger & 19 & 6 & 6 & 3 & 4 & 13.20 \\
\hline Aspergillus ochraceus & 1 & 1 & - & - & - & 0.69 \\
\hline Aspergillus terreus & 2 & 1 & 1 & - & - & 1.39 \\
\hline Diplodia natalensis & 9 & 2 & 1 & - & 6 & 6.29 \\
\hline Fusarium oxysporum & 2 & 2 & - & - & - & 1.39 \\
\hline Fusarium roseum & 1 & - & - & - & 1 & 0.69 \\
\hline Monilinia fructicola & 27 & 11 & 4 & 2 & 10 & 18.88 \\
\hline Penicillium digitatum & 2 & 1 & - & - & 1 & 1.39 \\
\hline Penicillium nigricans & 31 & 10 & 8 & 5 & 8 & 21.67 \\
\hline Rhizopus expansum & 8 & - & 3 & 3 & 2 & 5.59 \\
\hline Rhizopus stolonifer & 15 & 4 & 1 & 8 & 2 & 10.48 \\
\hline Stemphylium sp. & 3 & 2 & - & - & 1 & 2.09 \\
\hline Thamnidium elegans & 5 & 2 & 2 & - & 1 & 3.49 \\
\hline Unidentified sp. & 2 & 1 & 1 & - & - & 1.39 \\
\hline \hline Total & 143 & 48 & 32 & 23 & 40 & 99.179 \\
\hline
\end{tabular}

-: Not detected

The enzymatic activities for cellulolase and pectinase in the filtrates of fungi that inoculated on specific media for pectin and cellulose were studied. Pectinase activities by Aspergillus niger, Monilinia fructicola, Rhizopus stolonifer and Penicillium expansum was increased at optimum temperature, $\mathrm{pH} 7$ and $24 \mathrm{~h}$ incubation period. The production of pectin methyl esterase (PME) by the tested fungi was 28.3, 25, 10.3 and 9.8, while the production values for poly glactronase (PG) were 85.2, 83.15, 64 and 62.1, respectively. The tested fungi showed high ability to produce cellulolase enzyme, determined by increasing the viscosity and concentration of glucose.

The inhibition effects for acetic acid, chitosan and ozone water on the growth of the tested fungi in vitro were carried out. Acetic acid and chitosan with $6 \%$ concentration showed a high inhibitory effect against the tested fungi. The inhibitory effects for acetic acid and chitosan on Monilinia fructicola, Rhizopus stolonifer, 
Aspergillus niger and Penicillium expansum were 47 and 36.5\%; 35.3 and $42.4 \% ; 32.9$ and $35.3 \%$ and 30.5 and $29.4 \%$, respectively. The lowest concentration for inhibitory effect by chitosan was $3 \%$ and ozone water.

Table 4. The isolated fungi from four types of rot diseased fruits, Apricot, Cherry, Plum and Peach on PDA.

\begin{tabular}{|l|l|l|l|l|l|l|}
\hline Fungal isolates & No. of isolates & Apricot & Cherry & Peach & Plum & $\%$ of fungi \\
\hline Alternaria tenius & 14 & 5 & 4 & 4 & 1 & 5.1 \\
\hline Aspergillus candidus & 5 & 1 & 1 & 1 & 2 & 1.8 \\
\hline Aspergillus flavus & 20 & 7 & 6 & 5 & 2 & 7.2 \\
\hline Aspergillus humicola & 8 & 3 & 3 & 1 & 1 & 2.9 \\
\hline Aspergillus niger & 40 & 7 & 13 & 14 & 6 & 14.5 \\
\hline Aspergillus ochraceus & 7 & 3 & 3 & - & 1 & 2.5 \\
\hline Aspergillus terreus & 9 & 8 & - & - & 1 & 3.2 \\
\hline Diplodia natalensis & 13 & 5 & - & 6 & 2 & 4.7 \\
\hline Fusarium oxysporum & 5 & 1 & 2 & - & 2 & 1.8 \\
\hline Fusarium roseum & 5 & 2 & 2 & 1 & - & 1.8 \\
\hline Monilinia fructicola & 46 & 14 & 12 & 10 & 10 & 16.7 \\
\hline Penicillium digitatum & 4 & 1 & 1 & 1 & 1 & 1.4 \\
\hline Penicillium nigricans & 36 & 18 & 6 & 8 & 4 & 13.3 \\
\hline Rhizopus expansum & 10 & 3 & 3 & 3 & 2 & 3.6 \\
\hline Rhizopus stolonifer & 25 & 11 & 8 & 3 & 4 & 9.0 \\
\hline Stemphylium sp. & 7 & 2 & 2 & 1 & 2 & 2.5 \\
\hline Mucelia sterlia & 4 & 2 & 1 & 1 & - & 1.4 \\
\hline Thamnidium elegans & 7 & 2 & 1 & 2 & 2 & 2.5 \\
\hline Unidentified sp. & 6 & 2 & 2 & 1 & 1 & 2.1 \\
\hline \hline Total & 275 & 91 & 62 & 55 & 45 & 99.9 \\
\hline
\end{tabular}

Table 5 . Fungal infection percentages of four types of normal or injured fruits by four isolates of rot fungi $(\mathrm{N}=100)$

\begin{tabular}{|l|l|l|l|l|l|l|l|l|l|l|}
\hline & \multicolumn{4}{|c|}{ Normal fruits } & \multicolumn{4}{c|}{ Injured fruit } \\
\cline { 2 - 12 } & Apricot & Cherry & Peach & Plum & Mean & Apricot & Cherry & Peach & Plum & Mean \\
\hline Aspergillus niger & 32 & 11 & 29 & 25 & 24.2 & 80 & 33 & 75 & 65 & $\mathbf{6 3 . 3}$ \\
\hline Monilinia fructicola & 29 & 12 & 25 & 22 & 22.0 & 72 & 23 & 67 & 53 & $\mathbf{5 3 . 3}$ \\
\hline Penicillium expansum & 32 & 14 & 23 & 21 & 22.5 & 77 & 35 & 73 & 59 & $\mathbf{6 1 . 0}$ \\
\hline Rhizopus stolonifer & 35 & 18 & 32 & 29 & 28.5 & 90 & 55 & 85 & 75 & $\mathbf{7 6 . 2}$ \\
\hline \hline Mean & $\mathbf{3 2}$ & $\mathbf{1 3 . 7}$ & $\mathbf{2 7 . 3}$ & $\mathbf{2 4 . 3}$ & $\mathbf{2 4 . 3}$ & $\mathbf{7 9 . 8}$ & $\mathbf{3 6 . 5}$ & $\mathbf{7 5 . 0}$ & $\mathbf{6 3}$ & $\mathbf{6 5 . 8}$ \\
\hline
\end{tabular}

Table 6. Effect of different agar media on the growth $(\mathrm{mm})$ of the four tested fungi

\begin{tabular}{|l|l|l|l|l|}
\hline Tested fungi & $\begin{array}{l}\text { Rhizopus } \\
\text { stolonifer }\end{array}$ & $\begin{array}{l}\text { Penicillium } \\
\text { expansum }\end{array}$ & $\begin{array}{l}\text { Monilinia } \\
\text { fructicola }\end{array}$ & Aspergillus niger \\
\hline \hline Glucose peptone medium & 90.00 & 40.50 & 35.50 & 18.75 \\
\hline Potato dextrose & 90.00 & 39.00 & 76.75 & 90.00 \\
\hline Malt extract & 90.00 & 63.75 & 90.00 & 55.00 \\
\hline Capek's dox & 18.75 & 18.50 & 23.75 & 18.25 \\
\hline Richard's agar & 26.50 & 23.00 & 29.00 & 23.50 \\
\hline Yeast extract sucrose & 28.25 & 38.50 & 90.00 & 88.50 \\
\hline
\end{tabular}

\section{Discussion}

A wide range of microorganisms such as fungi can infect fruits and cause a serious threat to fruit production and making them less palatable, toxic and has bad taste, smell and appearance. Post-harvest pathology deals with fruit protection after harvesting, packing, transportation, processing, storage, and distribution. (Akinmusire, 2011, Chukwuka et al., 2010). In this study, a survey of the mycobiota associated with post-harvest rot of four types of fruits, plums, peaches, cherries, and apricots, collected from different localities of Jeddah was determined. Similarly, a survey of fungi associated with apple, banana, orange, mango and grape fruits were carried out and 39 species belonging to 16 fungal genera from the 150 mouldy fruit samples were isolated (Abdullah et al., 2016). Rhizopus stolonifer, Penicillium expansum, Aspergillus niger and Monilinia fruticola were the most dominant species. Abdullah et al. (2016) reported the genus Aspergillus on five types of mouldy fruits and A. niger and A. flavus were the commonest species. Similarly, Aspergillus were isolated from grapes, apples and orange (Gadgile and Chavan, 2010, Al-Hindi et al., 2011). Fruit transport time, humidity and temperature affect fungal growth and fruit rot (Fatima et al., 2012). Moreover, A. niger and Alternaria sp. cause mangoes rot in Saudi Arabia (Al-Hindi et al.., 2011). In this study, Penicillium was one of 
Postharvest rot diseases of some stone fruits collected from Jeddah city, Saudi Arabia..

Table 7. Effect of different incubation temperature on the growth $(\mathrm{mm})$ of the four tested fungi

\begin{tabular}{|c|c|c|c|c|}
\hline Temperature $\left({ }^{\circ} \mathrm{C}\right)$ & $\begin{array}{c}\text { Rhizopus } \\
\text { stolonifer }\end{array}$ & $\begin{array}{c}\text { Penicillium } \\
\text { expansum }\end{array}$ & Monilinia fructicola & Aspergillus niger \\
\hline 5 & 5.00 & 5.00 & 5.00 & 5.00 \\
\hline 10 & 5.00 & 5.00 & 5.00 & 5.00 \\
\hline 15 & 67.25 & 27.75 & 22.25 & 17.50 \\
\hline 20 & 87.50 & 36.00 & 36.75 & 36.00 \\
\hline 25 & 90.00 & 55.50 & 63.00 & 72.75 \\
\hline 30 & 90.00 & 74.00 & 66.00 & 30.25 \\
\hline 35 & 75.50 & 46.00 & 38.25 & 5.00 \\
\hline 40 & 5.00 & 6.75 & 5.00 & \\
\hline
\end{tabular}

Table 8. Effect of different $\mathrm{pH}$ value on the growth $(\mathrm{mm})$ of the four tested fungi

\begin{tabular}{|c|c|c|c|c|}
\hline $\mathrm{pH}$ & Rhizopus stolonifer & Penicillium expansum & Monilinia fructicola & Aspergillus niger \\
\hline 3.0 & 19.50 & 19.75 & 38.25 & 40.25 \\
\hline 4.0 & 31.75 & 20.75 & 48.00 & 57.75 \\
\hline 5.0 & 39.50 & 26.75 & 51.25 & 60.75 \\
\hline 6.0 & 41.75 & 39.00 & 51.03 & 72.50 \\
\hline 6.5 & 83.00 & 41.25 & 54.00 & 88.75 \\
\hline 7.0 & 85.00 & 74.00 & 76.50 & 90.00 \\
\hline 7.5 & 61.00 & 40.80 & 65.25 & 73.13 \\
\hline 8.0 & 30.75 & 21.50 & 66.25 & 60.50 \\
\hline 9.0 & 19.00 & 17.25 & 31.00 & 31.75 \\
\hline
\end{tabular}

Table 9. Inhibitory effect (diameter of inhibition zone, $\mathrm{mm}$ ) of 1\% Ozone, 3 and $6 \%$ Chitosan and 2\% Acetic acid on the four tested fungi

\begin{tabular}{|c|c|c|c|c|c|c|c|c|}
\hline \multirow{3}{*}{ Tested fungus } & \multirow{2}{*}{\multicolumn{2}{|c|}{$\begin{array}{l}\text { Ozone } \\
(1 \%)\end{array}$}} & \multicolumn{4}{|c|}{ Chitosan } & \multirow{2}{*}{\multicolumn{2}{|c|}{$\frac{\text { Acetic acid }}{(2 \%)}$}} \\
\hline & & & $6 \%$ & & 39 & & & \\
\hline & $\begin{array}{c}\text { Inhibition } \\
\text { Zone (mm) }\end{array}$ & $\%$ & $\begin{array}{l}\text { Inhibition } \\
\text { Zone (mm) }\end{array}$ & $\%$ & $\begin{array}{l}\text { Inhibition } \\
\text { Zone (mm) }\end{array}$ & $\%$ & $\begin{array}{l}\text { Inhibition Zone } \\
(\mathrm{mm})\end{array}$ & $\%$ \\
\hline Aspergillus niger & 19 & 22.4 & 30 & 35.3 & 25 & 29.4 & 28 & 32.9 \\
\hline $\begin{array}{l}\text { Monilinia } \\
\text { fructicola }\end{array}$ & 17 & 20 & 31 & 36.5 & 24 & 28.2 & 40 & 47 \\
\hline $\begin{array}{l}\text { Penicillium } \\
\text { expansum }\end{array}$ & 17 & 20 & 25 & 29.4 & 19 & 22.4 & 26 & 30.5 \\
\hline Rhizopus stolonifer & 22 & 25.9 & 36 & 42.4 & 30 & 35.3 & 30 & 30.3 \\
\hline
\end{tabular}

Table 10. Lytic enzyme production of the four tested fungi in liquid broth medium

\begin{tabular}{|c|c|c|c|c|}
\hline & \multicolumn{2}{|c|}{ Cellulase } & \multicolumn{2}{|c|}{ Pectinase } \\
\hline & Viscosity & Unite/ml & $\mathrm{PG}$ & PME \\
\hline Aspergillus niger & 80.5 & 15.8 & 85.20 & 28.3 \\
\hline Monilinia fructicola & 78.2 & 10.6 & 83.15 & 25.0 \\
\hline Penicillium expansum & 59.1 & 9.8 & 62.1 & 9.8 \\
\hline Rhizopus stolonifer & 88.2 & 21.32 & 64.0 & 10.3 \\
\hline
\end{tabular}

the commonest genera. Penicillium chrysogenum, $P$. citrinum, $P$. glabrum and $P$. viridicatum were isolated from grapes (Snowdon, 1990, Benkhemmar et al. 1993) while Narayanasamy (2006) isolated Penicillium from apple, citrus; grapes, pear, and strawberry. Dov Prusky et al. (2010) reported a decrease in pH value from 3.95- 4.3 to 3.6 -3.8 after fruit infection with P. expansum. On contrast, Cladosporium, Eupenicillium, Eurotium, Gliochladium, Fusarium, Rhizopus, Trichoderma, Ulocladium and Verticillium were rare on the different tested fruits (Abdullah et al., 2016). Fungal growth was affected by many factors including fruit type, water activity, $\mathrm{pH}$, temperature which play an important role on growth of fungi (Dantigny et al., 2005) and is the most ecological factors that affect fungal and evolution. Aspergillus isolates have a large range of temperature range 6-45 ${ }^{\circ} \mathrm{C}$ and $P$. verrucosum can produce ochratoxin at lower temperature conditions (Leong et al., 2006, Belli et al., 2005). Chitosan, acetic acid and ozone water were used for fungal inhibition. Similarly, vanillin, chitosan and chemical and natural acetic acid were used to control growth of Rhizopus (Yarahmadi et al., 2014). Rotted fungi are able to infect different fruits through their ability of production of many hydrolytic enzymes including pectinase and cellulase. As it is highly reported fungi are well known as a source of enzyme for decomposition of organic due to release of xylanase, cellulases (Lynd et al., 2002, Jahangeer et al., 2005). All the tested isolates of Erwinia and one isolate Rhizopus, caused soft rot of cabbage, exhibited significant differences in pectinase activities as confirmed by cup-plate and viscometric assays (Bhat et al., 2012). In conclusion, several fungal species are the common cause of rot disease for fruits due to production of lytic enzymes which lead to 
much economical loss. Preservation of fruits must be only for healthy fruits and under cool, clean and suitable conditions.

\section{References}

[1]. Abdullah, Q., Mahmoud, A., Al-harethi, A. (2016). Isolation and identification of fungal post-harvest rot of some fruits in Yemen. PSM Microbiol., 01(1): 36-44

[2]. Akinmusire, O.O. (2011). Fungal species associated with the spoilage of some edible fruits in Maiduguri Northern Eastern Nigeria. Advances in Environmental Biology, 5(1): 157-161.

[3]. Al-Hindi, R.R., Al-Najada, A.R., Mohamed, S.A., (2011). Isolation and identification of some fruit spoilage fungi: Screening of plant cell wall degrading enzymes. Afr. J. of Microbiol.

[4]. Snowdon, A.L., (1990). Color atlas of post-harvest diseases and disorders of fruits and vegetables, General Introduction and Fruits. CRC Press, Boca Raton FL. (1).302. Res., 5(4): 443-448.

[5]. Allen, S, E, Grimshaw, M.H, Parkinson, J.A. and Quarmby, C. (1974). Chemical Analysis of Ecological Materials. Blackwell's Scientific Publications, Oxford

[6]. Barnett, H. L. and Hunter, B. B. (1972). Illustrated genera of imperfect fungi. $3^{\text {rd }}$ ed., Burgess puh. Co. Burgers Co. Minneapolis, Minnesota. U.S.A.

[7]. Bauer, A.W., Kirby, W.M., Sherris J.C., Turck ,M., (1966). Antibiotic susceptibility testing by a standardized single disk method. American Journal of Clinical Pathology, 45(4), pp.493-496.

[8]. Belli, N., Ramos, A.J., Coronas, I., Sanchis, V., Marin, S. (2005). Aspergillus carbonarius growth and Ochratoxin A production in synthetic grape medium in relation to environmental conditions. Journal of Applied Microbiology, 98, p. 839-844.

[9]. Benhamou, N. (1992). Ultrastructural and cytochemical aspects of chitosan on F. oxysporum of sp. Radicis-lycopersici agent of tomato crown and root rot. Phytopath., 82 (10): 1185- 1193.

[10]. Benkhemmar, O., Lahlou, H., Dupont, J. (1993). Identification of different species of Penicillium causing deterioration of the Moroccan table grapes during storage. Mycopath., 124: 27-30

[11]. Bhargava, S. N.; Shukla, D. N. and Narendra, S.H. (1978). Postharvest disease of plum. Proc. Of the Nat. Acad of SG:, India, 48 (3) $: 168$.

[12]. Bhat, K.A., Bhat, N.A, Mohiddin F.A., Sheikh P.A. and Wani, A.H. (2012). Studies on pectinase activities of isolates of Erwinia carotovora and Rhizopus sp. causing soft rot in cabbage (Brassica oleracea var capitata L.). African Journal of Agricultural Research Vol. 7(45), pp. 6062-6067

[13]. Chopra, S., Mehta, A. and Mehta, P. (1989). Effect of antihistics in controlling the production of cell wall degrading enzymes in vitro and disease development. Hundustan Antibiot. Bull., 31 (3-4) : $83-89$.

[14]. Chukwuka, K.S., Okonko, I.O., Adekunle, A.A. (2010). Microbial ecology of organisms causing pawpaw (Carica papaya L.) Fruit decay in Oyo State, Nigeria. American-Eurasian J. Toxicol. Sci., 2 (1): 43-50.

[15]. Dahm, H., Stzzelczyk, E. and Manka, M. (1997). Production of cellulolytic and pectolytic enzymes by $F$. oxysporum, R. solani and T. viride. Phytopathologia, Potonica, 13: $19-30$.

[16]. Dantigny, P., Guilmart, A., Bensoussan, M. (2005). Basis of Predictive Mycology. Int. J. Food Microbiol., v. 100, p. $187-196$.

[17]. Dhingra, O.D. and Sinclair, J.C . (1985). Basic Plant Pathology Methods. CRC Press, Inc, Boca Ratan Florida.

[18]. Dzhafarov, I.G. (2002). Diseases of apricot fruit. Zashchita, I, Karantin Resteni; No. $6: 35$.

[19]. El-Ghaouth, A., Arul, J., Ponnampalam, R. and Boulet, M. (1991). Chitosan coating effect on storability and quality of fresh strawberries. Journal of Food Science, 56, 1618-20.

[20]. El-Ghaouth, A., Arul, J.; Grenier, J. and Asselin, A. (1992). Antifungal activity of Chitosan on two postharvest pathogens of strawbeury fruits. Phytopath., $82: 398-402$.

[21]. El-Shaieb, M.K.Z., Malibari, A.A. (1995). Enzymatic activities of soft rot causal organisms affecting vegetables and fruits in Saudi Arabia. Alexandria J. Agric. Res. 40(3):293-304.

[22]. Elshaieb, M. K. and Malibari, A. A. (1998). Enzymatic activities of soft rot causal organisms affecting vegetables and fruits in Saudi-Arabia. Alex. J. of Agric. Res., 40 (3) : 293 - 304.

[23]. El-Tobshy, Zeinab and Baraka, M. A. (1986). Control of postharvest disease of stone fruits. Ann. of Agric. Sci., Moshtohor, 24 : 21.

[24]. Fang, S.W., Li, C.F. and Shih, D.Y.C. (1994). Antifungal activity of chitosan and its preservative effect on low - sugar candied kumquat. J. Food, Prot., 57 (2) : $136-140$.

[25]. Fanti, L., De. R. and Rigo, G. (1996). Fungal diseases of stone fruits in veneto. Information Agario supptemento, 52 (15) : 10-12

[26]. Fatima, S., Baig, M., Kadam, V.B. (2012). Studies on management of Aspergilus rot of Amla. Int. J. Sci. 2

[27]. Gadgile, D.P., Chavan, A.M. (2010). Impact of temperature and relative humidity on development of Aspergillus niger rot of orange fruit. Sci. Technol., 3: 48-49.

[28]. Gilman, J. C. (1957). A manual of soil fungi : $2^{\text {nd }}$ Ed. The Iowa state Univ. Press. Ames, Iowa.

[29]. Ginting, C., Zehr, E. I and Westcott, S. W. (1996). Inoculum source and characterization of isolates of Gilbertella persicaria from peach fruit. Plant Disease, 80 (10): 1129-1134.

[30]. Gualandizzi, S, Folchi, A.; Neri, M.M.F.; Brigati, S. and pratella, G.C. (2001). Quality peach from the south. Rivista di Frutticoltura, e. di, Ortofloricoltura, 63 (10) 47-52.

[31]. Jahangeer, S., Khan, N., Jahangeer, S., Sohail, M., Shahzad, S., Ahmad, A. and Khan, S.A. (2005). Screening and characterization of fungal cellulases isolated from the native environmental source. Pak. J. Bot. 37, 739-748.

[32]. Jamaluddin, M. (1980). Organic acid composition of peach fruits during infection by A. flavus. Indian Phytopath., 32 (3) : 490.

[33]. Kovacs, G. (2001). Monilia on stone fruits "a long known disease" Planzenschutz, Wien, $17: 4$.

[34]. Kuzmanova, S., Vandeska, E. and Dimitrovski, A. (1991). Production of mycelial protein and cellulolytic enzymes from food waste. Journal of Industrial Microbiology. 7(4):257-261.

[35]. Leong, S.L., Hocking, A.D., Scott, E.S. (2006). Effect of Temperature and Water Activity on Growth and OchratoxinA Production by Australian Aspergillus carbonarius and A. niger Isolates on a Simulated Grape Juice Medium. Int. J. Food Microbiol., v. 110, p. 209-216.

[36]. Li, H. Y.; Yu, T.; and Li, H. (2001). Effect of chitosan on incidence of brown rot, quality and physiological attributes of postharvest peach fruit. J. of the Sci. of Food and Agric., 81 (2): 269-274.

[37]. Lynd, L.R., Weimer P.J., van Zyl, W.H., and Pretorius, I.S. (2002). Microbial cellulose utilization: fundamentals and biotechnology. Microbiol Mol Biolo Reviews, 66, 506-577.

[38]. Maiti, S.; Sahambi, S.H. and Ghosh, S.P. (1981). A new fruits rot of plum (Prunus domestica). Indian J. Mycol. and Plant Pathol., 9 (2) : 249 . 
[39]. Narayanasamy, P. (2006). Disease development and symptom expression. Cited in: Post-harvest Pathogens and Disease Management. Wiley- Interscience, John Wiley \& Sons, Inc.

[40]. Nasuno, S. and Starr, M.P. (1966). Polygalacturonase of Erwinia carotovora. J. Biol. Chem. 214:5298-5306.

[41]. Nelson, P.E., Toussoun, T.A. and Marasas, W.F.O. (1983). Fusarium species. An illustrated manual for identification. The Pennsylvania State Univ. Press, Univ. Park and London.

[42]. Prasad, J.; Shrma, G.K.; Pathak, V.N. and Verma, O.P. (1989). Effect of pH on the production of pectinolytic and cellulolytic enzymes by two fruit rotting fungi. Summa, Phytopathologica, 12 (1-2) : 132-136.

[43]. Raper, K.B. and Thom, G. (1949). A manual of Penicillium. The Williams and Wilkins Co. Baltimore U.S.A.

[44]. Ritchie, D.F. 2000. Brown rot of stone fruits. The Plant Health Instructor. DOI: 10.1094/PHI-I- 2000- 1025-01

[45]. Ritlenburg, L.H. and Hendrix, F.F. (1983). Peach fruit caused by Botrysphaesia species and Glomerella ingulata. Plant Dis. Rept. $67: 449-450$.

[46]. Roller, S. and Covill, N. (1999). The antifungal properties of chitosan in laboratory media and apple juice. Int. J. Food Microbiol., $47(1 / 2): 67-77$.

[47]. Sholberg, P.L. and Gaunce, A.P. (1996). Fumigation of stone fruit with acetic to control postharvest decay. Crop Protection, 15 (8) : 681-686.

[48]. Smith, W. K. (1958). A survey of the production of pectic enzymes by plant pathogenic and other bacteria. J. Gen. Microbiol., 18, 33

[49]. Spada, G. (1995). In effectiveness in 95 of defense methods against rots of peach and nectarine. Rivista, di Frutticoltura, e, di, ortofloricoltura, 57 (11): 37-38.

[50]. Subramanian, C.V. (1971). Hyphomycetes. An account of Indian speciesexept cercosporae. $1^{\text {st }}$ Ed. Indian Council of Agric. Res., New Delhi: 633-636.

[51]. Talboys, P.W., and Bush, L.V. (1970). Pectic enzymes produced by verticillium species. Trams. Br. Mycol. SOC., 55:367-381.

[52]. Thom, C. and Raper, K.B. (1945). Manual of Aspergillius. The Williams and Wilkins, Baltimore, USA.

[53]. Tosi, C., Spada, G., Ponti, I. and Tonini, G. (1996). Monilia rot in peach, nectarin and percoche. Rivista-di-Frutticoltura-e-diOrtofloricotura, 58 (7-8): 9-15.

[54]. Ugwanyi, J.O and Obeta, J.A.N. (1997). Some pectinolytic and cellulolytic enzyme activities of fungi causing rots of cocoyams. J. of the Sci., of food and Agric., 73 (4) : 432-436.

[55]. Wells, J.M. and Gerdts, K. (1971). Pre and postharvest benomyl treatments for control of brown rot of nectarines in California. Plant Dis. Reprt., $23: 69$.

[56]. Wokocha, R.C, (1990). Integrated control of Sclerotium rolfsii infection of tomato in the Nigeria savanna: effect of Trichoderma viride and some fungicides. Crop protection 9:231-234.

[57]. Yarahmadi M., Safaei Z. and Azizi M. (2014). Study the effect of chitosan, vanillin, and acetic acid on fungal disease control of Rhizopus stolonifer in strawberry fruits in vitro and in vivo European Journal of Experimental Biology, 2014, 4(3):219-225.

[58]. Zhull, J; Chang, Y.Y. and Chen, D.R. (1996). Study on the pathogen and control of apricot black spot disease. China Fruits, No 4 : 9-11. 